\title{
ROLE OF IRON IN THE NITRIC OXIDE-MEDIATED FUNGICIDAL MECHANISM OF IFN- $\gamma$-ACTIVATED MURINE MACROPHAGES AGAINST Paracoccidioides brasiliensis CONIDIA
}

\author{
Angel GONZALEZ(1,2), Angela ReSTREPO(1) \& Luz E. CANO(1,2)
}

\section{SUMMARY}

Iron is an essential growth element of virtually all microorganisms and its restriction is one of the mechanisms used by macrophages to control microbial multiplication. Paracoccidioides brasiliensis, the agent of paracoccidioidomycosis, an important systemic mycosis in Latin America, is inhibited in its conidia-to-yeast conversion in the absence of iron. We studied the participation of iron in the nitric oxide (NO)-mediated fungicidal mechanism against conidia. Peritoneal murine macrophages activated with $50 \mathrm{U} / \mathrm{mL}$ of IFN- $\gamma$ or treated with $35 \mu \mathrm{M}$ Deferoxamine (DEX) and infected with P. brasiliensis conidia, were co-cultured and incubated for $96 \mathrm{~h}$ in the presence of different concentrations of holotransferrin (HOLO) and $\mathrm{FeSO}_{4}$. The supernatants were withdrawn in order to assess $\mathrm{NO}_{2}$ production by the Griess method. The monolayers were fixed, stained and observed microscopically. The percentage of the conidia-to-yeast transition was estimated by counting 200 intracellular propagules. IFN- $\gamma$-activated or DEX-treated M $\theta$ s presented marked inhibition of the conidia-to-yeast conversion (19 and 56\%, respectively) in comparison with non-activated or untreated M $\theta$ s $(80 \%)$. IFN- $\gamma$-activated macrophages produced high NO levels in comparison with the controls. Additionally, when the activated or treated-macrophages were supplemented with iron donors $\left(\mathrm{HOLO}\right.$ or $\left.\mathrm{FeSO}_{4}\right)$, the inhibitory action was reversed, although NO production remained intact. These results suggest that the NO-mediated fungicidal mechanism exerted by IFN- $\gamma$-activated macrophages against $P$. brasiliensis conidia, is dependent of an iron interaction.

KEYWORDS: Paracoccidioides brasiliensis; Iron; Nitric Oxide; Peritoneal Murine Macrophages; IFN- $\gamma$.

\section{INTRODUCTION}

Paracoccidioides brasiliensis is the etiological agent of Paracoccidioidomycosis (PCM), a common systemic mycosis in Latin America $^{5}$. Natural infection begins with the inhalation of the conidia or mycelia fragments produced by the saprophytic phase of this thermally dimorphic fungal pathogen ${ }^{5}$. Histological studies have revealed that inhaled conidia quickly convert to the yeast form in the lungs of experimentally infected mice ${ }^{32}$. It has been shown that resident macrophages enhance the transition of conidia into yeast cells when compared with those in axenic culture medium with no macrophages; the yeast cells subsequently grow intracellularly by budding9. Additionally, resident pulmonary macrophages treated with cytokines from antigen-stimulated spleen cells from immunized mice were potent killers of conidia ${ }^{10}$.

BRUMMER et al. ${ }^{6}$. studied the fungicidal activity of peritoneal murine macrophages activated with recombinant gamma-interferon (rIFN- $\gamma$ ) against $P$. brasiliensis yeast cells and showed that killing was not significantly inhibited in the presence of superoxide dismutase, catalase, dimethylsulfoxide or azide. This indicated that the killing mechanism(s) against $P$. brasiliensis were not dependent upon products of the oxidative burst.

On the other hand, ARANGO \& RESTREPO ${ }^{2}$ studied the role of iron in the development and growth of both mycelial and yeast forms of $P$. brasiliensis and found that the fungus had a greater growth capacity in iron deficient media, probably because this deficiency enhanced ability of the fungus to produce iron chelants. CANO et al. ${ }^{11}$, demonstrated that iron restriction was one of the mechanism by which activated macrophages controlled intracellular transformation of ingested conidia and subsequent growth of yeast cells. Recently, it was demonstrated the role of intracellular iron in regulating the capacity of $P$. brasiliensis yeast cells to survive within human monocytes. In the latter work, the treatment of monocytes with deferoxamine, suppressed the survival of yeasts in a concentration-dependent manner and such effect was reversed by iron-saturated transferring (holotransferrin), suggesting that $P$. brasiliensis survival in human monocytes is iron dependent ${ }^{13}$.

Additionally, the use of specific or nonspecific nitric oxide (NO)inhibitors such as aminoguanidine, arginase or $\mathrm{N}^{\mathrm{G}}$-methyl-L-arginine, 
allowed to demonstrate that induction of NO production by IFN- $\gamma$ constitutes one of the killing mechanism that macrophages have against P. brasiliensis conidia ${ }^{18}$. However, an independent NO-mechanism is exerted by TNF-alpha-activated macrophages ${ }^{19}$.

NO is one the most important nitrogen intermediates; this molecule is generated by the oxidation of one of the nitrogen molecules of the aminoacid L-arginine ${ }^{20,21,22,39}$. NO is known to exert microbicidal or microbiostatic effect against a rapidly expanding list of microorganism ${ }^{12}$. The principal activities of the NO radical itself are revealed by superoxide $\left(\mathrm{O}_{2}^{-}\right)$, metals and thiols. Reaction of $\mathrm{NO}$ with superoxide produces peroxynitrite $\left(\mathrm{OONO}^{-}\right)$, a highly toxic and reactive molecule potentially capable oxidizing a variety of cellular targets. Reaction of NO with cellular iron or iron-sulfur centers can result in the inactivation of essential enzymes, including mitochondrial NADPH dehydrogenase, succinate dehydrogenase, ribonucleotide reductase, aconitase, as well ubiquinone reductase ${ }^{1,12}$. Once nitrosylated, these enzymes may lose iron and become inactive thus rendering the cell incapable of replicating; it may also increase the initial availability of $\mathrm{Fe}^{2+}$ augmenting the possibility of oxidative damage, and eventually, depleting cellular iron stores. Reaction with thiols can alter protein function and catalyze disulfide bond formation. NO may also react directly with DNA, resulting in deamination or cross-linking ${ }^{1,12}$.

The purpose of the present study was to determine if the fungicidal mechanism against $P$. brasiliensis conidia shown to be exerted by IFN$\gamma$-activated macrophages through NO-production, was associated with iron loss.

\section{MATERIAL AND METHODS}

Animals. Male BALB/c mice 8-12 weeks old, obtained from the breeding colony of the Corporación para Investigaciones Biológicas (CIB), in Medellín-Colombia, were used in all experiments. Mice were supplied with sterilized commercial food pellets, sterilized bedding and fresh acidified water and in accordance with the Colombian legislation (Ley 84, 1989, Res No. 8430 of 1993) and the European Community and Canadian Council on Animal Care (1998).

Reagents and media. Tissue culture medium RPMI 1640, fetal bovine serum (FBS), sulfanilamide, naphthylethylenediamine dihydrochloride, phosphoric acid $\left(\mathrm{H}_{3} \mathrm{PO}_{4}\right)$, deferoxamine mesylate (DEX), ferrous sulfate $\left(\mathrm{FeSO}_{4}\right)$ and holotransferrin (HOLO) were purchased from Sigma Chemical Co., St Louis, MO. Complete Tissue Culture Medium (CTCM) consisted of RPMI 1640 containing 10\% (vol/vol) heat-inactivated FBS (Sigma Chemical Co., St Louis), 100 U of penicillin and $100 \mu \mathrm{g}$ of streptomycin per mL. Recombinant mouse IFN- $\gamma$ was obtained from PharMingen, San Diego, CA.

Fungus and production of conidia. P. brasiliensis isolate (ATCC 60855) previously known to sporulate freely on special media, was used $^{38}$. All the procedures with this fungus were done using a Class II biological safety cabinet. The techniques used to grow the mycelial form and collect and dislodge conidia have been reported previously ${ }^{38}$. Briefly, the stock mycelial culture was grown in a liquid synthetic medium, the modified Mc Veigh-Morton broth at $18{ }^{\circ} \mathrm{C}( \pm 4)$ with shaking. Growth was homogenized and portions were used to inoculate agar plates; the latter were incubated at $18^{\circ} \mathrm{C}( \pm 4)$ for two months.
After this time, sterile physiological saline containing $0.01 \%$ Tween 20, $100 \mathrm{U}$ penicillin and $100 \mu \mathrm{g}$ streptomycin $\mathrm{mL}$ was used to flood the culture surface. Growth was removed with a bacteriological loop and the resulting suspension pipetted into an Erlenmeyer flask containing glass beads, which was then agitated in a reciprocating shaker at $250 \mathrm{rpm}$ for $30 \mathrm{~min}$. The homogeneous suspension was filtered through a syringe packed with sterile glass wool. The filtrate was collected in a polycarbonate centrifuge tube and centrifuged for 30 min at $1300 \mathrm{x}$ g; the pelleted conidia were washed, counted with a hemacytometer, and their viability assessed by the ethidium bromidefluorescein diacetate technique ${ }^{7,37}$. For the experiments, only inocula with a conidial viability $>90 \%$ were used.

Peritoneal murine macrophages. Peritoneal cells (PC) were collected individually from the abdominal cavity of $10-12 \mathrm{BALB} / \mathrm{c}$ mice by repeated lavage with $10 \mathrm{~mL}$ of fresh RPMI 1640 plus $100 \mathrm{U}$ of penicillin and $100 \mu \mathrm{g}$ of streptomycin per $\mathrm{mL}$ of media. PC from all mice were pelleted by centrifugation at $200 \mathrm{x} \mathrm{g}$, for $10 \mathrm{~min}$ and then pooled. PC were washed once and resuspended at $1 \times 10^{6}$ cell per $\mathrm{mL}$ of CTCM. A $0.25 \mathrm{~mL}$ volume of peritoneal cells was dispensed into each chamber of the eight-chambered Lab-Tek Slides (Nunc, Inc., Neperville IL). Cultures were incubated at $37{ }^{\circ} \mathrm{C}$ in $5 \% \mathrm{CO}_{2}-95 \%$ air for $2 \mathrm{~h}$, and then the non-adherent cells were removed by aspiration and the adherent macrophages rinsed with RPMI 1640. The number of non-adherent cells was determined and subtracted from the number of incubated PC. Approximately $2 \times 10^{5}$ adherent macrophages per chamber formed a monolayer ${ }^{9,10,18}$.

Treatment of macrophages. Macrophages monolayer were cultured for $18-24 \mathrm{~h}$ at $37{ }^{\circ} \mathrm{C}, 5 \% \mathrm{CO}_{2}-95 \%$ air in CTCM or in the presence of IFN- $\gamma(\text { at } 50 \mathrm{U} / \mathrm{mL})^{18}$. As a control on the specific effect of loss of iron, macrophages were exposed to an iron chelator (DEX at $35 \mu \mathrm{M})^{11}$. In addition, when supplements of exogenous iron were needed they were diluted in CTCM and added at different concentrations ( $25-200 \mu \mathrm{M}$ of $\mathrm{FeSO}_{4}$ and $0.05-6.0 \mathrm{mg} / \mathrm{mL}$ of HOLO) to macrophages in presence or not of IFN- $\gamma$ or DEX as described before ${ }^{11}$.

Infection of macrophages. Conidia were suspended in $2 \mathrm{~mL}$ of CTCM containing 30\% (vol/vol) fresh mouse serum from the same normal BALB/c mice used to obtain macrophages. Conidial suspensions were incubated at $37{ }^{\circ} \mathrm{C}$ for $20 \mathrm{~min}$ for opsonization to take place ${ }^{8}$. Macrophages monolayer were infected with $0.02 \mathrm{~mL}$ of the conidial suspension, which gave a conidium-to-macrophage ratio of $1: 10^{9,10,11,18,19}$.

Time course measurements. Co-cultures of $P$. brasiliensis conidia and peritoneal murine macrophages were incubated at $37{ }^{\circ} \mathrm{C}$ in $5 \%$ $\mathrm{CO}_{2}-95 \%$ air for $96 \mathrm{~h}$. After incubation, duplicate sets of culture supernatants were withdrawn and stored at $-70{ }^{\circ} \mathrm{C}$ for NO determination. The slides were fixed with absolute methanol, air dried and stained with Wright (Sigma Chemical Co., St Louis Mo, USA).

Microscopic determination of $\boldsymbol{P}$. brasiliensis intracellular transition. Over 200 intracellular $P$. brasiliensis fungal cells were examined per monolayer, and the morphology of the fungus, e.g., conidium, yeast cells or multiple budding yeasts, was recorded. The results were expressed as percentage of transformed fungal cells (yeast and multiple budding yeast $)^{19}$. 
Nitric oxide determination. $\mathrm{NO}_{2}$ concentration in culture supernatants was used as an indicator of NO generation and measured with the Griess reagent ( $1 \%$ sulfanilamide, $0.1 \%$ naphthylethylene diamine dihydrochloride, $\left.2.5 \% \mathrm{H}_{3} \mathrm{PO}_{4}\right)^{14}$. Briefly, $50 \mu \mathrm{L}$ of the coculture supernatants was added to an equal volume of Griess reagent in triplicate wells of a 96-well microplate; incubation was at room temperature for $10 \mathrm{~min}$. Absorbance $(540 \mathrm{~nm})$ was determined in a Labsystems Multiskan MCC/340 microplate reader. $\mathrm{NO}_{2}$ values were determined by using sodium nitrite as standard ${ }^{14}$.

Statistical analysis. Results are expressed as the average \pm standard error of mean for at least thrice and by duplicate experiments $(n=6)$. Comparisons between groups (untreated and treated M $\theta$ s) were analyzed by the student " $\mathrm{t}$ " test (Program STATISTIC for Windows, Version 5.0), with the significance level assumed to be $p<$ 0.05 .

\section{RESULTS}

IFN- $\gamma$ and DEX inhibit the $P$. brasiliensis conidia-to-yeast transition process within macrophages. We observed that when macrophages were exposed to IFN- $\gamma(50 \mathrm{U} / \mathrm{mL})$ or the iron chelator (DEX $35 \mu \mathrm{M})$, there was a significant $(p<0.000001)$ inhibition of the intracellular conidia-to-yeast transition process $(19.3 \pm 7.9 \%$ and 56.9 $\pm 6.1 \%$, respectively) when compared with control (non-activated macrophages cultured with CTCM alone; $80.0 \pm 6.6 \%$ ). Nonetheless, a marked effect was observed when IFN- $\gamma$ was used (Figs. 1 and 2).

Addition of exogenous iron reverses the inhibition on the $P$. brasiliensis intracellular conidia to yeast transition process exerted by IFN- $\boldsymbol{\gamma}$ or DEX. As shown in Fig. 1 , when IFN- $\boldsymbol{\gamma}$-activated-M $\theta$ s were supplemented with different concentrations of $\mathrm{FeSO}_{4}(25-200 \mu \mathrm{M})$ and infected with $P$. brasiliensis conidia, the inhibition of the transition process was reversed significantly $(p<0.000001)$ showing values of transition into yeast cells higher than $58 \%$ (Fig. 1A).

Similar results were observed, when IFN- $\gamma$-activated $\mathrm{M} \theta$ s were supplemented with HOLO $(0.05-6.0 \mathrm{mg} / \mathrm{mL})$, a reversion of the
A

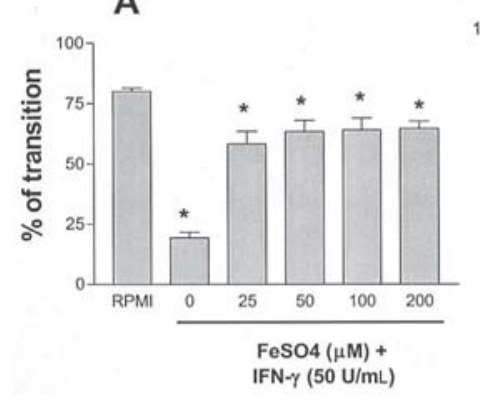

B

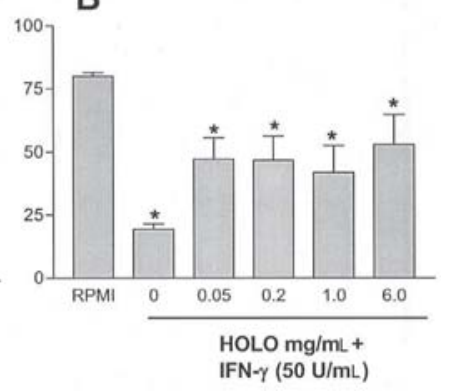

Fig. 1 - Effect of the addition of different concentrations of exogenous iron on the $P$. brasiliensis intracellular conidia-to-yeast transition process in murine peritoneal macrophages activated with IFN- $\gamma\left(50 \mathrm{U} / \mathrm{mL}\right.$ ). (A) $\mathrm{FeSO}_{4}$ or (B) holotransferrin (HOLO). Macrophages were pre-incubated with recombinant murine IFN- $\gamma$ during $18-24 \mathrm{~h}$ at $37^{\circ} \mathrm{C}(\mathrm{n}=6)$. After incubation macrophages were supplemented with the different iron donors and infected with P. brasiliensis conidia in a ratio 1:10. Range of bars represents the average \pm standard error of the mean. * Significant values $(p<0.000001)$. conidia-to-yeast transition process was also observed with values above $41 \%$ (Fig. 1B). No significant differences were obtained between the various concentrations of $\mathrm{FeSO}_{4}$ or $\mathrm{HOLO}$ used.

Addition of different concentrations of exogenous iron $\left(\mathrm{FeSO}_{4}\right.$ or HOLO) to macrophages treated with DEX, reversed the inhibitory effect on the conidia-to yeast transition process exerted by iron chelator in a significant manner $(p<0.0001)$ with transformation values being similar to the controls (higher than 76\%) (Fig. 2).
A

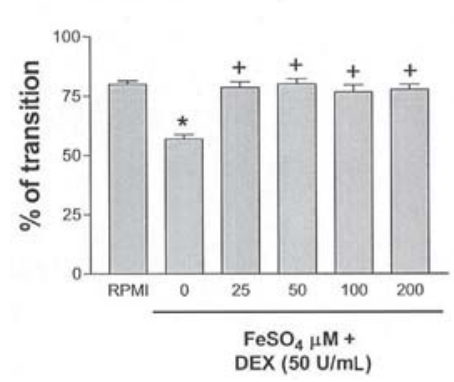

B

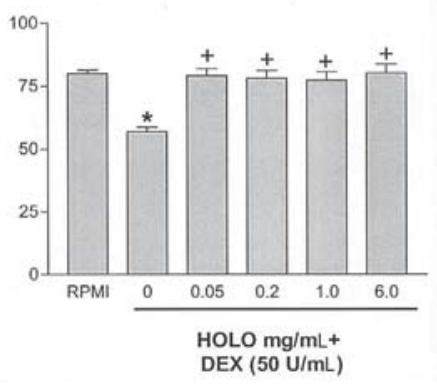

Fig. 2 - Effect of the addition of different concentrations of exogenous iron on the $P$. brasiliensis intracellular conidia-to-yeast transition process in murine peritoneal macrophages treated with DEX $(35 \mu \mathrm{M})$. (A) $\mathrm{FeSO}_{4}$ or (B) holotransferrin (HOLO). Macrophages were pre-incubated with DEX during $18-24 \mathrm{~h}$ at $37{ }^{\circ} \mathrm{C}(\mathrm{n}=6)$. After incubation macrophages were supplemented with the different iron donors and infected with $P$. brasiliensis conidia in a ratio $1: 10$. Range of bars represents the average \pm standard error of the mean. Significant values $* p<0.000001 ;+p<0.0001$.

Iron chelator (DEX) or the different iron donors $\left(\mathrm{FeSO}_{4}\right.$ or $\left.\mathrm{HOLO}\right)$, did not have any effect on viability of macrophages (data no shown).

IFN- $\boldsymbol{\gamma}$ but not DEX induces nitric oxide production. We observed that when macrophages were exposed to IFN- $\gamma(50 \mathrm{U} / \mathrm{mL})$, there was a significant $(p<0.000001)$ production of nitric oxide when compared with control (non-activated macrophages cultured with CTCM alone). How we were expected, not production of nitric oxide was observed when macrophages were treated with DEX (Figs. 3 and 4).
A

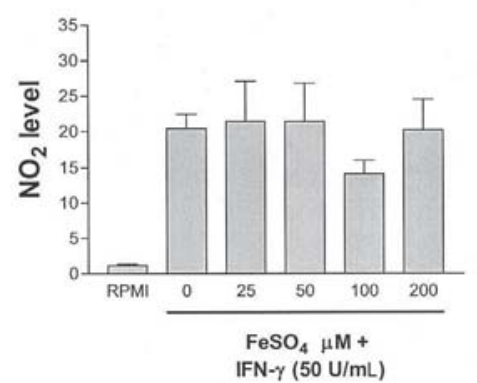

B

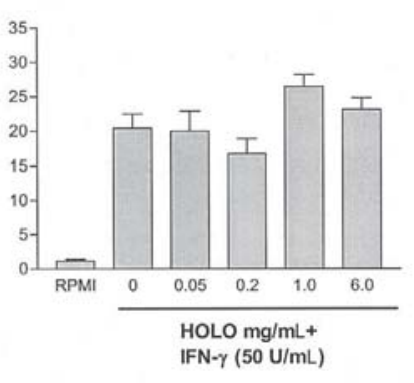

Fig. 3 - NO production by murine peritoneal macrophages activated with IFN- $\gamma(50 \mathrm{U} / \mathrm{mL})$. Macrophages were pre-incubated with recombinant murine IFN- $\gamma$ during $18-24 \mathrm{~h}$, and then infected with $P$. brasiliensis conidia as described in Material and Methods and supplemented with $\mathrm{FeSO}_{4}$ (A) or holotransferrin (HOLO) (B). Range of bars represents the average \pm standard error of the mean $(n=6)$. 
A

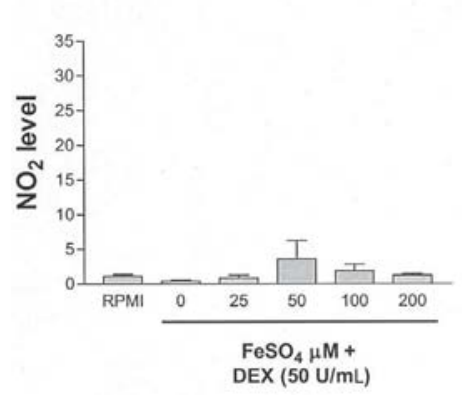

B

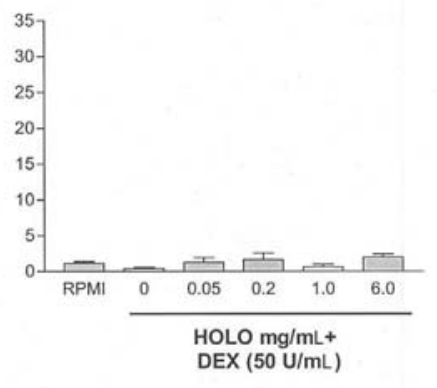

Fig. 4 - DEX did not affect the NO production by macrophages. Macrophages were preincubated with DEX $(35 \mu \mathrm{M})$ during 18-24 h, and then infected with P. brasiliensis conidia and supplemented with $\mathrm{FeSO}_{4}$ (A) or holotransferrin (HOLO) (B). Range of bars represents the average \pm standard error of the mean $(n=6)$.

Addition of the exogenous iron did not affect the nitric oxide production. The effect on NO production was determined after addition of exogenous iron to the IFN- $\gamma$ activated or the DEX treated macrophages, respectively.

As shown in the Fig 3, addition of either iron donor $\mathrm{FeSO}_{4}$ (A) or HOLO (B), did not affected NO production in IFN- $\gamma$-activatedmacrophages with values being similar to those in the activated nonsupplemented M $\theta$ s.

Treatment of macrophages previously exposed to DEX with either iron donors $\left(\mathrm{FeSO}_{4}\right.$ nor $\left.\mathrm{HOLO}\right)$ did not result in $\mathrm{NO}$ changes as shown in Fig. 4.

\section{DISCUSSION}

In the experiments reported here, it became apparent for the first time that the fungicidal activity exerted against $P$. brasiliensis conidia by IFN- $\gamma$-activated-macrophages through nitric oxide (NO) mediation, is associated with iron loss. The addition of exogenous iron (as holotransferrin or $\mathrm{FeSO}_{4}$ ) to co-cultures of IFN- $\gamma$-activated or DEXtreated-macrophages infected with $P$. brasiliensis resulted in the reversion of the inhibition conidia-to-yeast transition process.

The impact of iron on cell-mediated immunity has been substantiated previously in other reports demonstrating that iron-loaded macrophages lose their ability to kill intracellular pathogens by the IFN- $\gamma$-mediated pathways ${ }^{43}$.

In addition, other studies have shown that iron depletion from mouse peritoneal macrophages or human monocytes treated with DEX reduces the replication of some microorganisms such as Trypanosoma cruzi ${ }^{30}$, Histoplasma capsulatum ${ }^{27}$, and also P. brasiliensis ${ }^{11,13}$.

Maintenance of cellular iron homeostasis is indispensable for many essential biological processes and for the growth of organisms, and is also a central element in the regulation of immune function. Both iron deficiency and iron overload exert subtle effects on immune status with many of the biological effects attributed to NO being based on its interactions with iron. The inhibitory effects are given by interaction of NO with the central iron-sulphur clusters of the enzymes involved in DNA synthesis, mitochondrial respiration, citric cycle (Krebs), all of which result in increased formation of iron-nitrosyl complexes in cytotoxic activated monocytes/macrophages ${ }^{43}$.

In addition, iron is essential in $\mathrm{M} \theta$-mediated cytotoxicity by controlling NO production after activation by immunological stimuli ${ }^{15}$. Intracellular iron homoeostasis is usually controlled by cytoplasmic iron regulatory proteins (IRP1 and IRP2), which regulate expression of several proteins by binding to iron-responsive elements (IREs) on their $\mathrm{mRNA}^{4,17}$.

IRP binding activity is normally regulated by cellular iron level ${ }^{23,25}$, but can also be modulated by the NO produced by activated macrophages ${ }^{4,34,36}$. NO was shown originally to activate IRE-binding activity of both IRP1 and IRP $2^{34}$, although other authors ${ }^{3}$ have reported that activation of M $\theta$ s with IFN- $\gamma$ causes a down-regulation of IRP2 activity, despite production of NO.

Our results show that the exogenous addition of $\mathrm{FeSO}_{4}$ or $\mathrm{HOLO}$ to macrophages-conidia co-cultures inhibits the anti-fungal activity of activated macrophages, an observation that is consistent with previous reports of similar ferrous iron inhibition in macrophage cytotoxicity against various pathogens such as Schistosoma mansoni ${ }^{24}$, Leishmania ${ }^{31}$, Trypanosoma musculi ${ }^{42}$, H. capsulatum ${ }^{27,28}$ and Penicillium marneffe $i^{41}$.

LIN \& $\mathrm{CHADEE}^{29}$, found that when in the presence of $\mathrm{FeSO}_{4}$ macrophages activated with IFN- $\gamma$ plus LPS and exposed to Entamoeba histolytica, decrease by $50-80 \%$ their amebicidal activity. Low concentrations of $\mathrm{FeSO}_{4}(1.25$ to $10.0 \mu \mathrm{M})$ did not affect $\mathrm{NO}_{2}$ production, whereas a higher concentration $(50 \mu \mathrm{M})$ significantly decreased $\mathrm{NO}_{2}^{-}$levels. On the same taken, ZHANG et al. ${ }^{44}$, found that macrophages from rats chronically overloaded with iron had a significant diminution in nitric oxide release after stimulation with LPS and/or IFN- $\gamma$, stimulants that impair the ability of macrophages to inhibit the germination of Rhizopus spp. spores in a nitric oxidedependent process. LIN \& CHADEE $^{29}$ found that the addition of high concentrations of $\mathrm{FeSO}_{4}$ significantly decreased $\mathrm{NO}_{2}^{-}$production, indicating that iron could also inhibit macrophage toxicity by scavenging toxic nitrogen derivates into inactive nitrosyl-iron complexes. Contrary to these results, we found that when IFN- $\gamma$ activated macrophages were treated with different concentrations of $\mathrm{FeSO}_{4}, \mathrm{NO}_{2}^{-}$production was not affected. The effect of iron excess could have been due to protection or restoration in target cells, of irondependent enzymes that are sensitive to NO inactivation. It has been documented that NO reacts with Fe-S groups, resulting in the formation of iron-nitrosyl complexes that cause inactivation and degradation of the Fe-S prosthetic groups aconitase and complex I and complex II of the mitochondrial electron transport chain ${ }^{16,22,26,35,40}$. In contrast, in activated $\mathrm{M} \theta \mathrm{s}$ the oxidations of the terminal guanidine nitrogen of Larginine to form L-citrulline and NO required the induction of an enzymatic pathway. The NO produced competes with certain forms of iron or degrades it oxidatively to form $\mathrm{NO}_{2}^{-}$and $\mathrm{NO}_{3}^{-}$.

MENCACCI et al..$^{33}$, using a Candida albicans infection murine model, demonstrated that the effects of iron treatment on the expression of iNOS and of IL-12p40 genes were dependent on both type of cells and presence of infection. They showed that iron loading resulted in 
the disappearance of both types of messages in neutrophils cells (PMNs) from either uninfected or infected mice. In contrast, iron overload silenced the expression of both genes in macrophages from uninfected but not from infected mice.

Reaction of NO with cellular iron or iron-sulfur centers can result in the inactivation of essential enzymes (e.g. ribonucleotide reductase, aconitase and ubiquinone reductase) that may increase the initial availability of $\mathrm{Fe}^{2+}$ leading to potentiation of the oxidative damage and eventually depleting cellular iron stores ${ }^{12}$.

In conclusion, we have found that IFN- $\gamma$-activated M $\theta$ s exhibit antifungal effects on $P$. brasiliensis conidia through the L-argininedependent effector pathway and that this appears to selectively inducing the metabolic inhibition of the iron-containing enzymes.

\section{RESUMO}

\section{Papel do ferro no mecanismo fungicida mediado pelo óxido nítrico de macrófagos murinos ativados com IFN- $\gamma$ contra conídias do Paracoccidioides brasiliensis}

O ferro é elemento essencial para o crescimento de microrganismos e sua limitação é um dos mecanismos usados por macrófagos para controlar a multiplicação microbiana. Paracoccidioides brasiliensis, o agente da paracoccidioidomicose, uma das micoses sistêmicas mais importantes na América Latina, é inibido em sua conversão de conídiaà-levedura na ausência do ferro. Estudamos a participação do ferro no mecanismo fungicida mediado pelo óxido nítrico $(\mathrm{NO})$ na sua interação com as conídias do fungo. Macrófagos peritoneais murinos ativados com $50 \mathrm{U} / \mathrm{mL}$ de IFN- $\gamma$ ou tratados com $35 \mu \mathrm{M}$ Deferoxamina (DEX) e infectados com conídias do P. brasiliensis foram co-cultivados e incubados por $96 \mathrm{~h}$ na presença de concentrações diferentes de holotransferrina (HOLO) e $\mathrm{FeSO}_{4}$. Os sobrenadantes foram retirados a fim de avaliar a produção de $\mathrm{NO}_{2}$ pelo método de Griess. Os macrófagos eram fixados, corados e observados ao microscópio. A porcentagem da transição de conídia-à-levedura foi estimada contando 200 propágulos intracelulares. Os macrófagos ativados com citocina ou tratados com DEX apresentaram inibição marcada da conversão de conídia-à-levedura (19 e 56\%, respectivamente) em comparação com macrófagos controle ( $80 \%)$. Os macrófagos ativados com IFN- $\gamma$ produziram elevação nos níveis de $\mathrm{NO}$ em comparação com macrófagos não-tratados ou não-activados. Adicionalmente, quando as monocapas ativadas ou tratadas foram suplementadas com doadores do ferro ( $\mathrm{HOLO}$ ou $\mathrm{FeSO}_{4}$ ), a ação inibitória foi revertida embora a produção de NO permanecesse intacto. Estes resultados sugerem que o mecanismo fungicida mediado pelo NO exercido por macrófagos ativados com IFN- $\gamma$ contra conídias do $P$. brasiliensis é dependente de uma interação do ferro.

\section{ACKNOWLEDGMENTS}

This work was supported by the Instituto Colombiano para el Desarrollo de la Ciencia y la Tecnología, Francisco José de Caldas, COLCIENCIAS, Santafé de Bogotá-Colombia grant 2213-04-194-95, and the Corporación para Investigaciones Biológicas (CIB), Medellín, Colombia.

\section{REFERENCES}

1. ALSPAUGH, J.A. \& GRANGER, D.L. - Inhibition of Cryptococcus neoformans replication by nitrogen supports the role of these molecules as effectors of macrophage-mediated cytostasis. Infect. Immun., 59: 2291-2296, 1991.

2. ARANGO, R. \& RESTREPO, A. - Growth and production of iron chelants by Paracoccidioides brasiliensis mycelial and yeast forms. J. med. vet. Mycol., 26: 113-118, 1988.

3. BOUTON, C.; OLIVEIRA, L. \& DRAPIER, J.C. - Converse modulation of IRP1 and IRP2 by immunological stimuli in murine RAW 264.7 macrophages. J. biol. Chem., 273: 9403-9408, 1998.

4. BOUTON, C. - Nitrosative and oxidative modulation of iron regulatory proteins. Cell. Molec. Life. Sci., 55: 1043-1053, 1999.

5. BRUMMER, E.; CASTAÑEDA, E. \& RESTREPO, A. - Paracoccidioidomycosis: an update. Clin. Microbiol. Rev., 6: 89-117, 1993.

6. BRUMMER, E.; HANSON, L.H. \& STEVENS, D.A. - Gamma-interferon activation of macrophages for killing of Paracoccidioides brasiliensis and evidence for nonoxidative mechanism. Int. J. Immunopharmacol., 10: 945-952, 1988.

7. CALICH, V.L.G.; PURCHIO, A. \& PAULA, C.R. - A new fluorescent viability test for fungi cells. Mycopathologia (Den Haag), 66: 175-177, 1979.

8. CALICH, V.L.G.; KIPNIS, T.L.; MARIANO, M.; FAVA NETO, C. \& DIAS, W.D. - The activation of the complement system by Paracoccidioides brasiliensis "in vitro": its opsonic effect and possible significance for an in vivo model of infection. Clin. Immunol. Immunopath., 12: 20-30, 1979.

9. CANO, L.E.; ARANGO, R.; SALAZAR, M.E. et al. - Killing of Paracoccidioides brasiliensis conidia by pulmonary macrophages and the effect of cytokines. J. med. vet. Mycol., 30: 161-168, 1992.

10. CANO, L.E.; BRUMMER, E.; STEVENS, D.A. \& RESTREPO, A. - Fate of conidia from Paracoccidioides brasiliensis after ingestion by resident macrophages or cytokine-treated macrophages. Infect. Immun., 60: 2096-2100, 1992.

11. CANO, L.E.; GÓMEZ, B.; BRUMMER, E.; RESTREPO, A. \& STEVENS, D.A. Inhibitory effect of deferoxamine or macrophage activation on transformation of Paracoccidioides brasiliensis conidia ingested by macrophages: reversal by holotransferrin. Infect. Immun., 62: 1494-1496, 1994.

12. DE GROOTE, M.A. \& FANG, F.C. - NO Inhibitions: antimicrobial properties of nitric oxide. Clin. infect. Dis., 21(suppl. 2): S162-165, 1995.

13. DIAS-MELICIO, L.A.; CALVI, S.A.; PERACOLI, M.T. \& SOARES, A.M. - Inhibitory effect of deferoxamine on Paracoccidioides brasiliensis survival in human monocytes: reversal by holotransferrin not by apotransferrin. Rev. Inst. Med. trop. S. Paulo, 5: 263-266, 2005.

14. DING, A.H.; NATHAN, C.F. \& STUEHR, D.J. - Release of reactive nitrogen intermediates and reactive oxygen intermediates from mouse peritoneal macrophages. Comparison of activating cytokines and evidence for independent production. J. Immunol., 141: 2407-2412, 1988.

15. DLASKA, M. \& WEISS, G. - Central role of transcription factor NF-IL6 for cytokine and iron-mediated regulation of murine inducible nitric oxide synthase expression. J. Immunol., 162: 6171-6177, 1999.

16. DRAPIER, J.C. \& HIBBS Jr., J.B. - Differentiation of murine macrophages to express nonspecific cytotoxicity for tumor cells result in L-arginine-dependent inhibition of mitochondrial iron-sulfur enzymes in the macrophage effector cells. J. Immunol., 140: $2829-2838,1988$

17. EISENSTEIN, R.S. \& BLEMINGS, K.P. - Iron regulatory proteins, iron responsive elements and iron homeostasis. J. Nutr., 128: 2295-2298, 1998. 

conidia. Rev. Inst. Med. trop. S. Paulo, 49(1): 11-16, 2007.

18. GONZÁLEZ, A.; DE GREGORI, W.; VÉLEZ, D.; RESTREPO, A. \& CANO, L.E. Nitric oxide participation in the fungicidal mechanism of IFN- $\gamma$-activated murine macrophages against Paracoccidioides brasiliensis conidia. Infect. Immun., 68 $2546-2552,2000$

19. GONZÁLEZ, A.; ARISTIZÁBAL, B.H.; GÓMEZ, E.C.; RESTREPO, A. \& CANO, L.E - Inhibition by tumor necrosis factor-alpha-activated macrophages of the transition of Paracoccidioides brasiliensis conidia to yeast cells through a mechanism independent of nitric oxide. Amer. J. trop. Med. Hyg., 71: 828-830, 2004.

20. HIBBS Jr., J.B.; TAINTOR, R.R.; VAVRIN, Z. \& RACHLIN, E.M. - Nitric oxide: a cytotoxic activated macrophage effector molecule. Biochem. Biophys. Res. Commun., 157: 87-94, 1988.

21. HIBBS Jr., J.B.; TAINTOR, R.R. \& VAVRIN, Z. - Macrophage cytotoxicity: role for L-arginine deiminase and imino nitrogen oxidation to nitrite. Science, 235: 473 476, 1987.

22. HIBBS, Jr., J.B.; VAVRIN, Z. \& TAINTOR, R.R. - L-arginine is required for expression of the activated macrophage effector mechanism causing selective metabolic inhibition in target cells. J. Immunol., 138: 550-565, 1987.

23. IWAI, K.; DRAKE, S.K.; WEHR, N.B. et al. - Iron-dependent oxidation, ubiquitation, and degradation of iron regulatory protein 2: implications for degradation of oxidized proteins. Proc. nat. Acad. Sci. (Wash.), 95: 4924-4928, 1998

24. JAMES, S.L. \& GLAVEN, J. - Macrophage cytotoxicity against schistosomula of Schistosoma mansoni involves arginine-dependent production of reactive nitrogen intermediates. J. Immunol., 143: 4208-4212, 1989.

25. KENNEDY, M.C.; MENDE-MUELLER, L.; BLONDIN, G.A. \& BEINERT, H. Purification and characterization of cytosolic aconitase from beef liver and its relationship to the iron-responsive element binding protein. Proc. nat. Acad. Sci. (Wash.), 89: 11730-11734, 1992

26. LANCASTER Jr., J.R. \& HIBBS Jr., J.B. - EPR demonstration of iron-nitrosyl complex formation by cytotoxic activated macrophages. Proc. Nat. Acad. Sci. (Wash.), 87 $1223-1227,1990$

27. LANE, T.E.; WU-HSIEH, B.A. \& HOWARD, D.H. - Iron limitation and the gamma interferon-mediated antihistoplasma state of murine macrophages. Infect. Immun., 59: 2274-2278, 1991

28. LANE, T.E.; WU-HSIEH, B.A. \& HOWARD, D.H. - Gamma interferon cooperates with lipopolysaccharide to activate mouse splenic macrophages to an antihistoplasma state. Infect. Immun., 61: 1468-1473, 1993.

29. LIN, J.Y. \& CHADEE, K. - Macrophage cytotoxicity against Entamoeba histolytica trophozoites is mediated by nitric oxide from L-arginine. J. Immunol., 148: 39994005, 1992.

30. LOO, V.G. \& LALONDE, R.G. - Role of iron in intracellular growth of Trypanosoma cruzi. Infect. Immun., 45: 726-730, 1984

31. MAUEL, J.; RANSIJN, A. \& BUCHMULLER-ROULLER, Y. - Killing of Leishmania parasites in activated murine macrophages is based on an L-arginine-dependent process that produces nitrogen derivates. J. Leuk. Biol., 49: 73-82, 1991.
32. McEWEEN J.G.; BEDOYA, V.; PATINO, M.M.; SALAZAR, M.E. \& RESTREPO, A. Experimental murine paracoccidioidomycosis induced by inhalation of conidia. J. med. vet. Mycol., 25: 165-175, 1987.

33. MENCACCI, A.; CENCI, E.; BOELAERT, J.R. et al. - Iron overload alters innate and T helper cell responses to Candida albicans in mice. J. infect. Dis., 175: 1467-1476, 1997.

34. PANTOPOULOS, K.; WEISS, G. \& HENTZE, M.W. - Nitric oxide and oxidative stress $\left(\mathrm{H}_{2} \mathrm{O}_{2}\right)$ control mammalian iron metabolism by different pathways. Molec. cell. Biol., 16: $3781-3788,1996$.

35. PELLAT, C.; HENRY, Y. \& DRAPIER, C.J. - IFN- $\gamma$-activated macrophages: detection by electron paramagnetic resonance of complexes between $\mathrm{L}$-arginine-derived nitric oxide and non-heme iron proteins. Biochem. Biophys. Res. Commun., 166: 119125,1990 .

36. RECALCATI, S.; TARAMELLI, D ; CONTE, D \& CAIRO, G. - Nitric oxide-mediated induction of ferritin synthesis in $\mathrm{J} 774$ macrophages by inflammatory cytokines: role of selective iron regulatory protein-2 downregulation. Blood, 91: 1059-1066, 1998.

37. RESTREPO, A.; CANO, L.E.; DE BEDOUT, C.; BRUMMER, E. \& STEVENS, D.A. Comparison of various techniques for determining viability of Paracoccidioides brasiliensis yeast-form cells. J. clin. Microbiol., 16: 209-211, 1982.

38. RESTREPO, A.; SALAZAR, M.E.; CANO, L.E. \& PATIÑO, M.M. - A technique to collect and dislodge conidia produced by Paracoccidioides brasiliensis mycelial form. J. med. vet. Mycol., 24: 247-250, 1986.

39. STUEHR, D.J.; KWON, N.S.; GROSS, S.S. et al. - Synthesis of nitrogen oxides from Larginine by macrophages cytosol: requirement for inducible and constitutive components. Biochem. Biophys. Res. Commun., 161: 420-426, 1989.

40. STUEHR, D.J. \& NATHAN, C.F. - Nitric oxide: a macrophage product responsible for cytostasis and respiratory inhibition in tumor target cells. J. exp. Med., 169: 1543$1555,1989$.

41. TARAMELLI, D.; BRAMBILLA, S.; SALA, G. et al. - Effects of iron on extracellular and intracellular growth of Penicillium marneffei. Infect. Immun., 68: 1724-1726, 2000 .

42. VINCENDEAU, P. \& DAULOUEDE, S. - Macrophage cytostatic effect on Trypanosoma musculi involves an L-arginine-dependent mechanism. J. Immunol., 146: 43384343, 1991.

43. WEISS, G.; WACHTER, H. \& FUCHS, D. - Linkage of cell-mediated immunity to iron metabolism. Immunol. today., 16: 495-500, 1995.

44. ZHANG, Y.; CRICHTON, R.R.; BOELAERT, J.R. et al. - Decreased release of nitric oxide (NO) by alveolar macrophages after in vivo loading of rats with either iron or ethanol. Biochem. Pharmacol., 55: 21-25, 1998.

Received: 27 March 2006

Accepted: 1 August 2006. 